\title{
Development of the Arctic regions of the Russian Federation: drivers of greening
}

\author{
Elena Voronina ${ }^{1, *}$ \\ ${ }^{1}$ Institute of System Analysis of FITs IU of the Russian Academy of Sciences, 119333, Moscow, \\ Vavilov St., 44, building 2, Russia
}

\begin{abstract}
The article considers the principles of ecological-socioeconomic development of the Arctic territories of the Russian Federation in the context of global climate changes and increasing anthropogenic and man-made loads. Currently, Russia is implementing priority projects in the Arctic zone of the Russian Federation, which are strategically significant and play an important socio-economic role in the development of regions and the national economy. The study proves that the transformation process of the economic system is necessary. It is based on "green" standards with the help of greening drivers for the socio-economic environmental development of the Arctic territories under global climate changes and increasing man-made loads. The principles of greening make it possible to organize economic activity in a systematic way; to ensure sustainability, balance and the social orientation of functioning. This is also motivated by Russia's international obligations within the Arctic Council, responsible for carrying out the coherent policy of the Arctic countries in the field of environmental protection and sustainable development of the macro-region.
\end{abstract}

\section{Introduction}

Nowadays, the ideas of economic, social and environmental balance of development as well as harmonization between nature and society are not something new. However, the economic transformation based on "green" standards, the economic greening and the idea of systemic development are gaining special relevance for Russian society, taking into account global development $[1,2,3]$. Socio-economic environmental development implies an orientation towards achieving harmony between society and nature. In general, it involves the acquisition of the eco-development nature.

Considering the development of the region as a complex structured system with multidimensional and multifaceted connections, it is inappropriate to solve only the problems of economic efficiency of functioning. So, the regional reproduction process also includes the reproduction of the human himself and the quality of his natural environment. The balanced development of the region includes three equal components: economic, social and environmental. Thus, the interdependence of these components is constantly increasing.

\footnotetext{
*Corresponding author: vep73@,rambler.ru
} 
Recently, the natural factor (the quality of the environment) has an increasingly tangible effect on the distribution of productive forces.

It is clear that this assertion is a fundamental factor for the Arctic territories of the Russian Federation. Compliance with this condition is absolutely necessary to ensure the unique nature and quality of the environment conservation.

\section{Materials and method}

To solve the problems of environmental protection and environmental sustainability, an interdisciplinary synthesis of knowledge is required: socio-economic and demographic, environmental-economic, energy-economic. Following this approach, the balanced socioeconomic development of the region, for which rational principles and methods of management are selected, is considered as a co-evolutionary development of nature and society [4]. The most important principles of such development are: preservation of high quality of the environment, economic growth with balanced nature management, solution of social problems (creation of good living environment). Equilibrium nature management is focused on balanced consumption and reproduction of natural resources. The quality of the social environment is expressed in improving the well-being and quality of life through allocating the necessary resources to maintain an ecological balance. That is possible only on the basis of effective, environmentally friendly economic development, which determines its ability to maintain sustainability (co-evolutionary development of nature and society). By the way, it is important to take into account two circumstances. Firstly, economic growth increases anthropogenic impacts on the natural environment through the depletion of resources. Secondly, the introduction of only waste-free, resource-saving and environmental technologies does not solve the problem of maintaining the equilibrium state of ecosystems during the exploitation of natural resources (beyond the permissible limits). The identification and preservation of such characteristics of the natural environment that determine its ability to maintain stability (co-evolutionary development of nature and society) should act as a policy of balanced nature.

It is quite obvious that this statement is especially important for the Arctic zone of the Russian Federation. The Arctic is an extremely difficult region for economic activity and the organization of human life in extreme natural and climatic conditions. There are very close connections between the components: economic, social and environmental. This fact predetermines the urgent need for the co-evolutionary development of nature and society. Currently, there is a lack of coordination between sectoral and territorial management of socio-economic environmental development. Thus, it is one of the main reasons for the existing imbalances and imbalances. It is obvious that the paradigm of the socio-economic development of the Arctic regions of the Russian Federation should be knowledge, innovation, modernization in the interests of balanced environmental management and saving the unique ecological systems of the Arctic and its viability.

So, the priority areas of economic transformation should be innovations, including those of an environmental nature, which make profound changes in the nature of labor and production. As well as in the means and forms of meeting the material and spiritual needs of human capital, including natural benefits, forming the human environment, health and rest. In this regard, there is an urgent need for the use of more modern environmentally friendly technologies, the creation of new high-tech industries and the introduction of higher requirements in the field of environmental protection in the implementation of economic activities. It is necessary to transform the economy based on "green" standards, taking into account sustainable nature management and eco-efficiency due to a number of reasons: 
- ensuring national environmental security. The goals of state policy are the preservation and restoration of the natural environment; ensuring the quality of the environment, which is necessary for a favorable human life and sustainable development of the economy; eliminating the accumulated harm to the environment due to economic and other activities in the context of increasing economic activity and global climate change [5];

- balanced solution of problems of sustainable nature management and eco-efficiency for the future. The need to preserve a favorable state of the environment and natural resource potential in order to meet the vital needs of both living and future generations of people [6];

- vital condition for environmentally balanced development is the integration of environmental objectives into economic and sectoral approaches (for example, in such industries as energy, natural resource extraction, transport, housing and communal services). It is necessary to green the types and results of economic activities, which will reduce anthropogenic effect on the environment and reduce the harmful effects on the health of the population $[7,8]$.

\section{Results and discussion}

The transformation of the socio-economic system is set by certain drivers. Thus, it should proceed from the development trends of a socially oriented society. The society is aimed at an economically, environmentally and socially effective interconnected combination of its elements. The elements consist of improving the regulatory framework for environmental protection, including the introduction of economic incentives business entities for the introduction of environmentally efficient technologies [9].

By the way, it is important to emphasize, that the socio-economic system is complexly structured and it is formed by heterogeneous, but very interdependent elements. The weakening of any connection inevitably entails a decrease in the level of integrity of the entire system. The integrity of the socio-economic system is mostly due to the influence of many processes, which are usually considered in terms of a set of goals.

According to the previous results, ecological-socio-economic development should be based on co-evolutionary development in compliance with the mandatory requirements of greening. This requires institutional and structural changes. The changes those are implemented through the use of various mechanisms. At the same time, the drivers in the system of institutions are promising directions for reforming the regulatory framework of environmental policy and economic activity. The structural transformation drivers are innovations and investments. So, investment projects are based on public-private partnerships for the development and implementation of innovations with the help of scientific and educational institutions, as well as business structures. Accordingly, the drivers of the socio-economic environmental development should be the following: improvement of organizational and economic instruments for rational use of natural resources and environmental protection; achieving social security (improving the human environment); the use of high technologies by business entities for the environmental friendliness of production processes.

There are four main directions of greening socio-economic development [10]:

- "ecology of production" is based on a phased reduction of the levels of environmental impact from all anthropogenic sources;

- "human ecology" provides for the creation of an environment-friendly and comfortable living for the population (places of work and rest and other social activities);

- "business ecology", including the creation of an effective ecological sector of the economy: competitive business in the field of mechanical engineering, business 
development, environmental consulting, widespread introduction of environmental management, monitoring the dynamics of environmental indicators of the economy;

- "ecology of the natural environment", which provides the preservation and protection of the natural environment based on the use of new methods of territorial planning, land use and development, taking into account environmental restrictions (Fig.1).

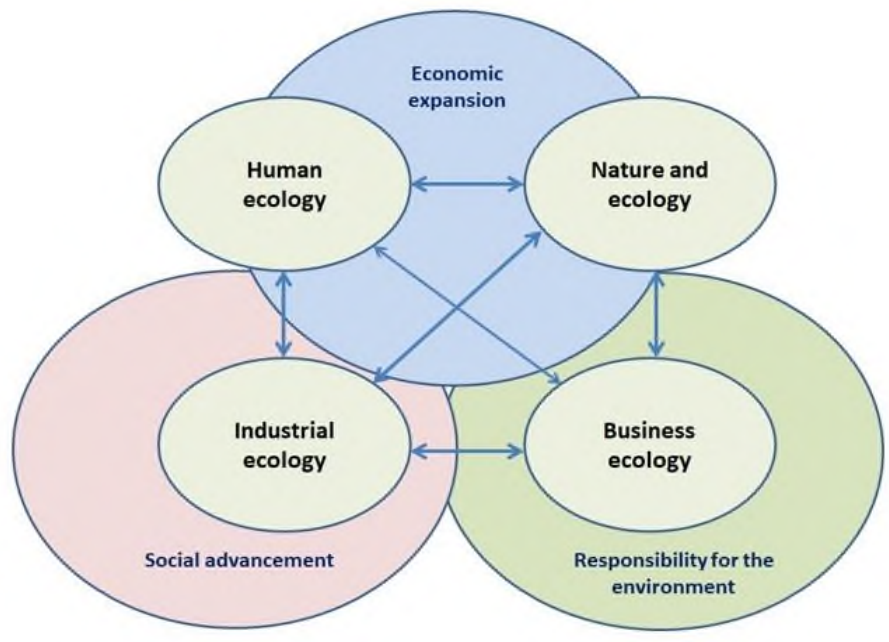

Fig. 1. Areas of greening.

The greening of socio-economic development is a system determined by the sequence of processes and based on the interconnection and interdependence of all its directions (Fig. 2). The system of greening the socio-economic development makes it possible to systematically organize social needs and hierarchy of goals and criteria for the development of social production. It also makes possible to remove restrictions and contradictions between economic activity and the natural environment and to ensure the stability and balance of the relationships between natural, economic and social characteristics of the equilibrium state of the ecosystem.

\begin{tabular}{|c|c|c|}
\hline Input (drivers) & $\begin{array}{c}\text { Transformation } \\
\text { process }\end{array}$ & Output \\
\hline $\begin{array}{l}\text { Improvement of } \\
\text { organizational and economic } \\
\text { instruments for } \\
\text { environmental management } \\
\text { (rational use of natural } \\
\text { resources) and } \\
\text { environmental protection; } \\
\text { achieving social } \\
\text { availability (improving the } \\
\text { human environment); } \\
\text { the use of high-tech } \\
\text { products by subjects of } \\
\text { innovation for the } \\
\text { production processes } \\
\text { greening. }\end{array}$ & $\begin{array}{l}\text { Ensuring the safety of } \\
\text { natural resources, establishing } \\
\text { restrictions on the impact on } \\
\text { the environment: } \\
\text { bringing to justice for } \\
\text { violation of environmental } \\
\text { legislation; } \\
\text { promotion of scientific } \\
\text { researches and development } \\
\text { workin the field of } \\
\text { environmental protection, } \\
\text { resource conservation and } \\
\text { environmental safety; } \\
\text { development of economic } \\
\text { motivation for implementation } \\
\text { of environmental measures; } \\
\text { environmental } \\
\text { entrepreneurship support; } \\
\text { attracting investment in } \\
\text { environmental management } \\
\text { and protection. }\end{array}$ & $\begin{array}{l}\text { Improving the } \\
\text { quality of the natural } \\
\text { environment and the } \\
\text { environmental } \\
\text { conditions of human } \\
\text { life; } \\
\text { development of a } \\
\text { balanced, ecologically } \\
\text { oriented model of } \\
\text { economic } \\
\text { development. }\end{array}$ \\
\hline
\end{tabular}

Fig. 2. The socio-economic environmental development greening system. 
Obstacles to the ecological-socio-economic development of the Arctic zone of Russia are its extremely vulnerable nature, physical-geographical and natural-climatic features (taking into account the low stability of ecological systems, affecting all types of human activity and the associated environmental restrictions of economic activity). This need to use the modern technologies adapted to the Arctic conditions and environmentally friendly environmental management systems. These systems impose special requirements on economic activity in the Arctic zone in terms of the environmental discipline of economic behavior.

According to these, new challenges for economic activity are arising in the Arctic. It is happening in compliance with modern geopolitical and economic requirements for environmental protection to maintain the natural potential and environmental friendliness of production processes [11]. This implies the use of effective technical and technological solutions, coordination of the activities of resource users, their interaction in the development of programs for economic development and long-term planning, support and implementation of resource-saving and environmental technologies.

Accordingly, the intensification of industrial activity in the Russian Arctic zone in the modern geo-economic environment is possible only through the use of the results of fundamental research and the achievements of applied science and the latest innovative technologies. Using the modern Russian scientific developments, it is possible to reach a long-term effect for technological development in a large number of Russian industries. In this case, a significant result can be achieved in the greening of industrial activities in the Arctic (energy, transport, extraction and development of natural resources, life support systems). As an example, the possible options for greening economic and social activities, improving the quality of the living environment of society and the biodiversity of the Russian Arctic region can be considered. It is based of high-tech developments of Russian scientists in Arctic materials science (Table 1).

Table 1. Drivers of greening the economic and social activities based on high-tech achievements in Arctic materials science. Source: [12].

\begin{tabular}{|c|c|c|}
\hline Materials - drivers of greening & Scope of application & $\begin{array}{l}\text { Result of greening } \\
\text { drivers application }\end{array}$ \\
\hline $\begin{array}{l}\text { Metals: metals and alloys with sufficient } \\
\text { strength, frost resistance and high } \\
\text { anticorrosive properties. } \\
\text { Ceramics: heat-resistant glass. } \\
\text { Polymers: thermoplastics and frost-resistant } \\
\text { plastics; adhesives and sealants for } \\
\text { low temperatures; organofluoric anti-icing } \\
\text { coatings; hydrophobic polymeric and } \\
\text { oligomeric materials; frost-resistant and fire- } \\
\text { resistant rubbers. } \\
\text { Composites: hydrophobic materials resistant } \\
\text { to temperature extremes; ice-based } \\
\text { composites; with sufficient strength and frost } \\
\text { resistance ones; cold-resistant building } \\
\text { composite materials; composite heat- } \\
\text { insulating materials based on mineral } \\
\text { reinforcing fillers. } \\
\text { Fuels and lubricants: liquid fuels and } \\
\text { lubricants operating at negative temperatures }\end{array}$ & $\begin{array}{l}\text { Transport } \\
\text { infrastructural } \\
\text { facilities and } \\
\text { services. } \\
\text { Facilities providing } \\
\text { mineral extraction } \\
\text { and exploration. } \\
\text { Transport facilities } \\
\text { of goods and } \\
\text { people. } \\
\text { Capital and } \\
\text { residential } \\
\text { construction } \\
\text { facilities. }\end{array}$ & $\begin{array}{l}\text { Prevention of the } \\
\text { environmental } \\
\text { hazards. } \\
\text { Establishment of safe } \\
\text { and accident-free } \\
\text { operation of objects. } \\
\text { Ensuring safety of } \\
\text { the carriage } \\
\text { Ensuring comfortable } \\
\text { living, travel and } \\
\text { work conditions for } \\
\text { residents. }\end{array}$ \\
\hline
\end{tabular}




\section{Conclusion}

The problem of the socio-economic environmental development of the Arctic zone is primarily based on an assessment of the specifics of this region, which will inevitably affect all the economic processes and also the analysis of interdependent social, economic, scientific, technical and environmental factors of development. In principle, the use of the natural resources of the Arctic territories, ensuring a decent standard of living for the population and organizing economic activities in accordance with natural and ecological conditions is a complex integral integrated system (Fig.3).

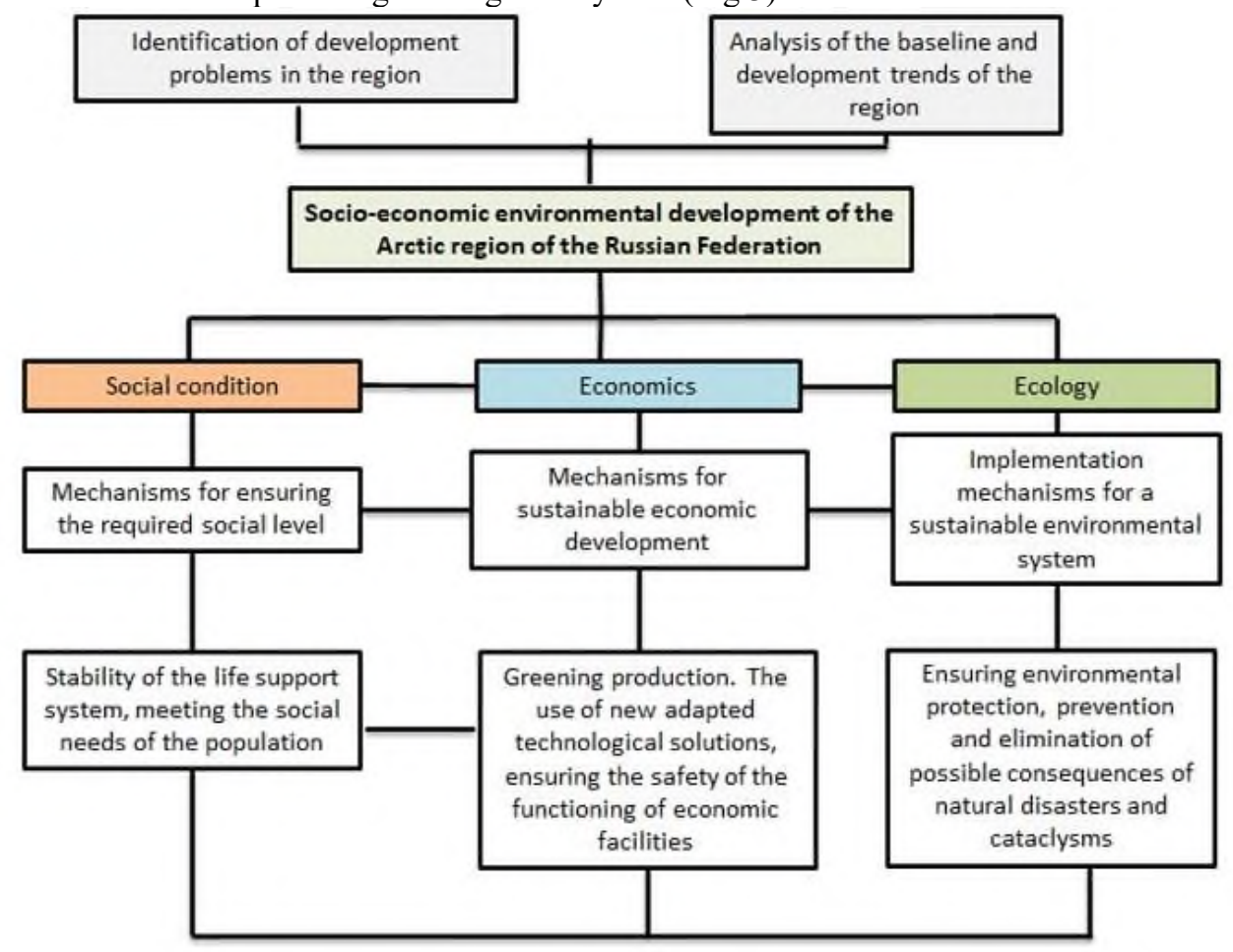

Fig. 3. Conceptual scheme of the socio-economic environmental development of the Arctic region of the Russian Federation.

The integrated system of the socio-economic environmental development of the Arctic region of the Russian Federation is a sequence of actions, in which each step ensures the implementation for the next step, the integration and cooperation of support mechanisms and also the use of administrative, technological, legal levers to improve management efficiency.

According to the intensification of industrial activity in the Arctic zone, which is presented as national projects, the importance of environmentally responsible economic behavior and compliance with the requirements for environmental protection are especially significant. This fact is due to the danger of global climatic changes and their impact on permafrost, the development of hazardous natural processes, an increase in the level risks and scale of damage from man-made accidents and natural disasters.

The economy of the Arctic territories should be mostly based on the progressive scientific and technical achievements in the field of chemistry, physics, microbiology and other sciences. The development of an extremely difficult climate zone is not expressed as much in increasing of the population, labor resources and GRP, as in active work on the 
development and use of new knowledge and in the introduction of advanced technologies. It is necessary to strengthen the communication in the "science-production" system (the organization of scientific, technical and innovative activities, in a timely response to scientific and technical achievements and their use to optimize the implementation of Arctic projects).

Thus, it can be noted that socio-economic environmental development mostly depends on the adaptive and successful transformation of the economy based on "green" standards with the help of greening drivers. The drivers allow organizing the natural environment, economic and social activities systematically, removing contradictions between them and ensure sustainability, balance and social orientation of functioning. This system is a modern form of organizing the life of society of an integration-synthesizing nature. In essence, there is a new habitat formation, in which all four areas of greening must fully realize their potential and their capabilities. The drivers of socio-economic environmental development modify this environment from the old format of interaction between society and nature to a new one. They contribute to the expansion and deepening of interconnections and interdependencies between elements and all spheres of society and give a significant economic and social effect in conclusion. All of this makes it possible to meet material and spiritual needs of the population the most effectively and to rationally carry out social reproduction. Compliance with all the requirements for environmental friendliness of economic management in the Arctic region will simultaneously become both a maturity test and a significant reserve for the country's economic development. Since high-tech industries contribute to the formation of a highly productive material and technical base, they contribute to the transition from a pure raw material to a resource-innovative development scenario.

\section{References}

1. L.S. Kabir, Government Stimulus Package to Help Modernization through "Green" Technology as a Measure to Meet the Challenges to the Russian Economy, Economy. Taxes. Right 3, 58-63 (2016)

2. B.A. Morgunov, A.M. Bagin, M.L. Kozeltsev, A.A. Terentiev, Problems of Environmental Safety of Russia in the Light of the "Green" Growth Concept, Human Ecology 4, 3-11 (2017) DOI: 10.33396/1728-0869-2017-4-3-11

3. B.N. Porfir'ev, Green economy: worldwide development trends and prospects, Herald of the Russian Academy of Sciences 82, 2, 120-128 (2012) DOI: $10.1134 / \mathrm{S} 1019331612020074$

4. V.N. Lazhentsev, The methodological approaches to the strategic planning of sustainable development of the territorial economic systems, Proceedings of the Komi Science Center Ural Branch RAS 1(13), 107-113 (2013)

5. Strategy of environmental safety of the Russian Federation for the period up to 2025 [Electronic resource]. URL: http://docs.cntd.ru/document/420396664

6. V.S. Selina, T.P. Skufina, E.P. Bashmakova (under scientific.) The north and the arctic in the new global development paradigm: challenges, trends, prospects. Scientific and analytical report (Apatity: Kola Science Center RAS, 2016)

7. A. I. Tatarkin, Russian Arctic: a modern development paradigm (St. Petersburg: Nestor-History, 2014)

8. V.V. Ivantera, The Arctic space of Russia in the XXI century: development factors, management organization (SPb. : Publishing House "Science", 2016) 
9. Basic principles of the State policy in the field of environmental development of the Russian Federation for the period up to 2030 (approved by the President of the Russian Federation 30.04.2012) [Electronic resource]. URL: http://www.consultant.ru/cons/cgi/online.cgi?req=doc\&cacheid=A9202CF15464BE4B B2C2B27829B797D7\&mode $=$ backrefs \&div $=$ LAW\&opt $=1 \&$ SORTTYPE $=0 \& B A S E N$ $\mathrm{ODE}=1-$

$1 \&$ ts $=17202155163225212964 \&$ base $=$ LAW $\& n=129117 \&$ rnd $=082$ BFBDC8D315A2C B1BDA42A599A28D5\#3x14x20k3ts

10. The concept of sustainable socio-economic development of the RF [Electronic resource] URL: http://www.consultant.ru/online/base/?req=doc;base=LAW;n=90601

11. Russia's priorities in the Arctic, Special report to the International Forum of Technological Development "Technoprom-2016" (Novosibirsk, 2016)

12. V.M. Buznik, E.N. Kablov, Arctic materials science: current state and prospects, Herald of the Russian Academy of Sciences 87, 5, 397-408 (2017) DOI: $10.1134 / \mathrm{S} 101933161705001 \mathrm{X}$ 